University of Nebraska - Lincoln

DigitalCommons@University of Nebraska - Lincoln

\title{
Evaluating effects of deficit irrigation strategies on grain sorghum attributes and biofuel production
}

\author{
Bairen Pang \\ Kansas State University, bairen@ksu.edu \\ Ke Zhang \\ Kansas State University \\ Isaya Kisekka \\ University of California, Davis, ikisekka@ucdavis.edu \\ Scott Bean \\ USDA-ARS, scott.bean@ars.usda.gov \\ Meng Zhang \\ Kansas State University, meng@k-state.edu \\ See next page for additional authors
}

Follow this and additional works at: https://digitalcommons.unl.edu/usdaarsfacpub

Pang, Bairen; Zhang, Ke; Kisekka, Isaya; Bean, Scott; Zhang, Meng; and Wang, Donghai, "Evaluating effects of deficit irrigation strategies on grain sorghum attributes and biofuel production" (2018). Publications from USDA-ARS / UNL Faculty. 1850.

https://digitalcommons.unl.edu/usdaarsfacpub/1850

This Article is brought to you for free and open access by the U.S. Department of Agriculture: Agricultural Research Service, Lincoln, Nebraska at DigitalCommons@University of Nebraska - Lincoln. It has been accepted for inclusion in Publications from USDA-ARS / UNL Faculty by an authorized administrator of DigitalCommons@University of Nebraska - Lincoln. 


\section{Authors}

Bairen Pang, Ke Zhang, Isaya Kisekka, Scott Bean, Meng Zhang, and Donghai Wang 


\title{
Evaluating effects of deficit irrigation strategies on grain sorghum attributes and biofuel production ${ }^{\text {is }}$
}

\author{
Bairen Pang a, 1 , Ke Zhang a, 1 , Isaya Kisekka ${ }^{b}$, Scott Bean ${ }^{c}$, Meng Zhang ${ }^{\mathrm{d}}$, \\ Donghai Wang ${ }^{\text {a, * }}$ \\ a Department of Biological and Agricultural Engineering, Kansas State University, Manhattan, KS, 66506, USA \\ b Department of Biological and Agricultural Engineering, University of California Davis, CA, 95616-5270, USA

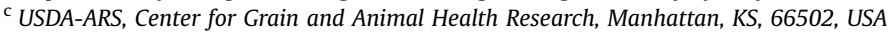 \\ d Department of Industrial and Manufacturing Systems Engineering, Kansas State University, Manhattan, KS, 66506, USA
}

\section{A R T I C L E I N F O}

\section{Article history:}

Received 13 June 2017

Received in revised form

5 September 2017

Accepted 7 September 2017

Available online 8 September 2017

\section{Keywords:}

Deficit irrigation

Grain sorghum

Starch content

Bioethanol yield

\begin{abstract}
A B S T R A C T
With reduced water resources available for agriculture, scientists and engineers have developed innovative technologies and management strategies aimed at increasing efficient use of irrigation water. The objective of this research was to study the impact of deficit irrigation strategies on sorghum grain attributes and bioethanol production. Grain sorghum was planted at Southwest Research-Extension Center near Garden City, KS, under five different irrigation capacities ( 1 inch every 4, 6, 8,10, or 12 days) and dryland in 2015 and 2016 growing seasons. Results showed average kernel weight, kernel diameter and test weight of grain sorghum increased as irrigation capacity increased, whereas kernel hardness index decreased as irrigation capacity increased. Starch and protein contents of sorghum ranged from 69.45 to $72.82 \%$ and $8.22-12.50 \%$, respectively. Starch pasting temperature and peak time decreased as irrigation capacity increased. Irrigation capacity had a positive impact on bioethanol yield, whereas both year and interaction between irrigation capacity and year did not show significant effect on bioethanol yield resulting from above normal rainfall received during the growing seasons.
\end{abstract}

() 2017 Elsevier Ltd. All rights reserved.

\section{Introduction}

In the United States, $\sim 80 \%$ of the nation's consumptive water use is used for agriculture and more than $90 \%$ of the nation's water in many semi-arid and arid areas (USDA-ERS, 2016). Irrigation is an essential technology as it supplements inadequate rainfall to enhance crop yield. However, the availability of water for irrigation has been decreased due to the depletion of the Ogallala Aquifer (McGuire, 2012) in areas such as the southern High Plains. With reduced water resources for agriculture, scientists and engineers have developed innovative technologies and management strategies aimed at increasing the efficient use of irrigation water including deficit irrigation strategies.

\footnotetext{
Names are necessary to report factually on available data; however, the U.S. Department of Agriculture neither guarantees nor warrants the standard of the product, and use of the name by the U.S. Department of Agriculture implies no approval of the product to the exclusion of others that may also be suitable.

* Corresponding author.

E-mail address: dwang@ksu.edu (D. Wang).

${ }^{1}$ First two authors contributed equally to this work.
}

Researchers have studied the effects of limited or deficit irrigation on crop yield. Van Donk et al. (2010) studied yield response of corn to deficit irrigation in west-central Nebraska. Their research showed that it takes $65-100 \mathrm{~mm}$ of water for an extra yield of $1.6 \mathrm{Mg} \mathrm{ha}{ }^{-1}$ of corn. Irmak et al. (2016) evaluated the effects of deficit irrigation on corn production and developed crop yield response factors for field corn. Wheat yield, biomass, and water productivity response to deficit irrigation was studied in western KS (Berhe et al., 2017). El-Hendawy et al. (2017) also studied the effects of full and limited irrigation on wheat growth (El-Hendawy et al., 2017) as well. Zhang et al. (2016) reported rice production improved $4-8 \%$ and reduced $20.5 \%$ water consumption using regulated deficit irrigation and fuzzy control in Heilongjiang province, China. Chai et al. (2016) reviewed the influence of regulated deficit irrigation on crop production under drought stress in terms of growth stage-based deficit irrigation, partial root-zone irrigation and subsurface dripper irrigation.

Grain sorghum response to water and deficit irrigation management has been studied extensively in Kansas by several investigators (Araya et al., 2016; Kisekka et al., 2016; Klocke et al., 
2012; Stone and Schlegel, 2006). These studies in Kansas show that grain sorghum is a good crop under water limited scenarios and has potential to reduce income risk compared to corn over time. In addition to crop yield, deficit irrigation can also significantly impact crop quality and other non-food application, such as bioethanol production.

In the United States, 200 operating ethanol biorefineries in 28 states produced a record 15.25 billion gallons of bioethanol in 2016 , along with 42 million metric tons of high-protein animal feed as byproducts (RFA, 2016). The majority of bioethanol was produced from corn with only $\sim 4 \%$ produced from grain sorghum. While an overall minor component of total bioethanol production, the portion of bioethanol made from sorghum represents $\sim 45 \%$ of the grain sorghum produced in the United States, primarily in plants located in the High Plains regions (RFA, 2016). With the increase in bioethanol production, corn has become overused as a renewable source, which may impact the amount of corn used for human food and directly as animal feed consumption. If all of the corn in the United States was converted into bioethanol, it would only meet $25 \%$ of that needed to replace gasoline (Conca, 2014).

Grain sorghum has good potential as a bioethanol crop due to its fit as a more cost effective crop for semiarid regions in the United States (Yan et al., 2011). In 2015, grain sorghum production increased by $38 \%$ compared with 2014, while corn production decreased by $4 \%$ (USDA-NASS, 2016). This shift in production demonstrates there is a possibility for grain sorghum to be incorporated at greater rates in bioethanol production and to move towards less dependence on corn alone.

Previous research has been carried out to evaluate grain sorghum for bioethanol production. Wu et al. (2007) reported that high starch content and low viscosity during liquefaction were favorable characteristics for the conversion of grain sorghum to bioethanol, whereas tannin content and low protein digestibility had negative impacts. Yan et al. (2011) evaluated the fermentation performance of waxy grain sorghum for ethanol production and reported that the advantages of using waxy sorghums for ethanol production include easier gelatinization and low viscosity during liquefaction, higher starch, and protein digestibility, higher free amino nitrogen (FAN) content, and shorter fermentation times.

Our previous research reported effect of irrigation levels on sorghum physical and chemical properties and ethanol yield (Liu et al., 2013). In this study, we focus on the impact of deficit irrigation strategies (detailed in Irrigation Management) on sorghum grain attributes and bioethanol production.

\section{Materials and methods}

\subsection{Field experimental}

The experiment was conducted at the Kansas State University Southwest Research-Extension Center Finnup farm near Garden City, KS, with latitude and longitude of $38^{\circ} 01^{\prime} 20.87^{\prime \prime} \mathrm{N}$, $100^{\circ} 49^{\prime \prime} 26.95 \mathrm{~W}$ and elevation of $887 \mathrm{~m}$ above mean sea level. The soil at the experimental site is characterized as a deep well drained Ulysses silt loam with organic matter content of $1.5 \%$ and $\mathrm{pH}$ of 8.1. The climate is semi-arid with mean annual precipitation of $450 \mathrm{~mm}$.

\subsubsection{Irrigation management}

The study was conducted under a lateral move sprinkler irrigation system modified to apply irrigation water in any desired treatment combination. The experimental design was a randomized complete block design with four replications and six treatments: 1) full irrigation,100\% evapotranspiration (ET); 2) $50 \%$ ET irrigation prior to booting of grain sorghum, $100 \%$ ET after boot and total irrigation limited to $250 \mathrm{~mm}$; 3) 100\% ET irrigation (total irrigation limited to $250 \mathrm{~mm}$ ); 4) 50\% ET irrigation prior to booting of grain sorghum, and 100\% ET after boot, and total irrigation limited to $150 \mathrm{~mm}$; 5) 100\% ET irrigation (total irrigation limited to $150 \mathrm{~mm}$ ); and 6) dryland.

As a case study, two limitations on total irrigation were compared to full irrigation as described in Kisekka et al. (2016). The limitations were 150 and 250 inches. The fully irrigated treatment was managed as a non-water limiting crop with $100 \%$ ET replenishment. Soil water in the $2.4 \mathrm{~m}$ soil profile was measured as a check for adequacy of the ET-based irrigation schedule and also for determination of crop water use. Soil water measurements were made using neutron scattering technique (neutron probe). Inseason irrigation events were adjusted to account for rainfall amounts received during the growing season. Total irrigation applications in 2015 were 194, 169, 169, 169, 169, and $44 \mathrm{~mm}$ for treatments 1 through 6 , respectively. Total irrigation applications in 2016 were $244,194,244,169,194$, and $16 \mathrm{~mm}$ for treatments 1 through 6 respectively.

\subsubsection{Agronomic management}

The hybrid used was Pioneer 84G62, because it is full season and well adapted under both irrigated and dryland environments. Grain sorghum was planted at a seeding rate of 40,485 seeds per hectare on June 4, 2015 and on May 23, 2016. Best management practices for fertilizer and weed control for high yielding grain sorghum were followed. For example, at planting 10:34:0 fertilizer was applied at a rate of $15 \mathrm{l} / \mathrm{ha}$ and at least $179 \mathrm{~kg} \mathrm{~N} / \mathrm{ha}$ was applied. Some of the herbicides used for weed control included atrazine $4 \mathrm{~L}$ at rate of $383 \mathrm{~mL} /$ ha and Lumax EZ at a rate of $958 \mathrm{~mL} / \mathrm{ha}$. Grain sorghum was harvested on October 20, 2015, and October 13, 2016.

\subsection{Sample preparation and grinding}

Sorghum was cleaned using a Gamet sieve shaker (Dean Gamet Manufacturing, Minneapolis, MN) with a $6.35 \mathrm{~mm}$ screen to remove broken kernel and small foreign material. Large broken kernels and foreign materials were manually pick removed. An UDY sample cyclone mill (UDY Corporation, Fort Collins, CO) equipped with a $0.5 \mathrm{~mm}$ screen was used to grind clean samples into flour. Afterward, ground sorghum was sealed in plastic bags and stored in a sealed plastic box at a laboratory with stable environmental conditions of $25^{\circ} \mathrm{C}$ and $30 \%$ humidity.

\subsection{Physical properties of sorghum}

Sorghum 1000 kernel weight, single kernel diameter, and hardness were analyzed using a SKCS 4100 (Perten Instruments, Huddinge, Sweden) as previously reported (Bean et al., 2006). Test weights of sorghum samples were determined according to the AACC International Method 55-10.01 "Test Weigh per Bushel". Moisture contents of sorghum samples were determined according to the AACC International 44-15.02 "Moisture Air-Oven Methods".

\subsection{Chemical composition of grain sorghum}

Total starch contents of grain sorghum samples were determined according to the AACC (Method 76.13.01) using a Megazyme starch assay kits (Megazyme International Limited Company, Ireland). Megazyme Mega-Calc ${ }^{\mathrm{TM}}$ software (Megazyme International Limited, Ireland) was used to calculate the total starch content from the absorbance data and the moisture content based on a dry weight basis. Protein, fat, and fiber contents of grain sorghum samples were determined according to AOAC official methods 990.03-2002, 920.39-1920 and 962.09-2010, respectively. 


\subsection{Thermal property of grain sorghum by differential scanning calorimetry (DSC) analysis}

Thermal properties of sorghum samples including onset temperature, peak temperature and gelatinization enthalpy were determined using a differential scanning calorimetry (DSC) (DSCQ200, TA Instruments Incorporation, New Castle, DE). The method has been described previously by Zhang et al. (2017). 8 $\mathrm{mg}$ sorghum flour was mixed with $\sim 24 \mu \mathrm{L}$ of distilled water in a stainless steel pan before placing in a $4{ }^{\circ} \mathrm{C}$ freezer overnight. The method of analysis included for that sample was isothermal at $25^{\circ} \mathrm{C}$ for $2 \mathrm{~min}$ and then heated to $180{ }^{\circ} \mathrm{C}$ at the speed of $10^{\circ} \mathrm{C} \mathrm{min}-1$.

\subsection{Pasting properties of grain sorghum using rapid viscosity analysis (RVA)}

Pasting properties of sorghum samples including pasting temperature, peak time, peak viscosity, breakdown, final viscosity, and setback, were determined using a rapid viscosity analyzer (RVA) (RVA-3c, Newport Scientific Limited Company, Warriewood, Australia). The AACC method (76-21.01) was applied as the analysis method: $3.5 \mathrm{~g}$ sorghum sample with $14 \%$ moisture content was mixed with $\sim 25 \mathrm{~g}$ distilled water in a canister. The slurry was dispersed by stirring at $960 \mathrm{rpm}$ for $10 \mathrm{~s}$ then and at $160 \mathrm{rpm}$ for the rest analysis. The slurry was held at $50^{\circ} \mathrm{C}$ for $1 \mathrm{~min}$ prior to heating up to $95{ }^{\circ} \mathrm{C}$. The slurry was held at $95{ }^{\circ} \mathrm{C}$ for $2.5 \mathrm{~min}$ before decreasing back to $50{ }^{\circ} \mathrm{C}$, where the slurry was held for $2 \mathrm{~min}$.

\subsection{Bioethanol fermentation}

The bioethanol fermentation process including liquefaction and saccharification, fermentation, and distillation were as described previously (Zhang et al., 2017). Briefly, $30 \mathrm{~g}$ of dry sorghum flour mixed with $100 \mathrm{~mL}$ distilled water plus fermentation media in 250$\mathrm{mL}$ Erlenmeyer flask. Next, $20 \mu \mathrm{L}$ Liquozyme SC DC $(240 \mathrm{KNU} / \mathrm{g}$, $\sim 1.26 \mathrm{~g} / \mathrm{mL}$, Novozymes, New York, NY) and $100 \mu \mathrm{L}$ Spirizyme Achieve $(750 \mathrm{AGU} / \mathrm{g}, \sim 1.15 \mathrm{~g} / \mathrm{mL}$, Novozymes, New York, NY) were added for starch hydrolysis and saccharification, respectively. One $\mathrm{mL}$ activated yeast pre-culture (Red Star Ethanol Red, Lasaffre, France) was added after adjusting the $\mathrm{pH}$ of slurry to $4.2-4.3$ with $2 \mathrm{~N} \mathrm{HCl}$.
The fermentation was conducted at $30{ }^{\circ} \mathrm{C}$ in an incubator shaker (Model I2400, New Brunswick Scientific, Edison, NJ) operating at $150 \mathrm{rpm}$ for $72 \mathrm{~h}$. After the fermentation was completed, the finished beer was entirely transferred to a $500-\mathrm{mL}$ distillation flask. Each Erlenmeyer flask was washed with a total volume of $100 \mathrm{~mL}$ distilled water. Distillates were collected into a $100-\mathrm{mL}$ volumetric flask until approaching the $100 \mathrm{~mL}$ mark ( $\sim 99 \mathrm{~mL})$. Bioethanol was determined using a high performance liquid chromatograph (Agilent, Santa Clare, CA) equipped with a Rezex RCM column (Phenomenex, Torrance, CA) and refractive index detector (Zhang et al., 2017).

\subsection{Scanning electron microscope (SEM) images}

A scanning electron microscope (SEM) with an accelerating voltage of $5.0 \mathrm{kV}$ (Hitachi S-3500N, Hitachi Science Systems, Limitation Company, Tokyo, Japan) was used to determine the morphological structure of sorghum grain. In preparation, some sorghum grain was cracked with a hammer to obtain small and flat fragments. A Desk II combined sputter coater covered the samples with a mixture of $60 \%$ gold and $40 \%$ palladium under vacuum conditions (Denton Vacuum, Moorestown, NJ).

\subsection{Statistical analysis}

Statistical analysis was conducted using the PROC GLIMMIX procedure in SAS (SAS Institute, Cary, NC). Correlation analysis was implemented using Pearson's correlation. All statistical analysis were conducted at a $5 \%$ level of significance.

\section{Results and discussion}

\subsection{Effect of deficit irrigation on physicochemical properties of grain sorghum}

Table 1 summarizes physiochemical properties of sorghum under six deficit irrigation management strategies in 2015 and 2016. The mean and range across irrigation capacities and years were $25.56 \mathrm{~g}$ and $21.96-29.67 \mathrm{~g}$ for 1000 kernel weight, $2.4 \mathrm{~mm}$ and $2.19-2.62 \mathrm{~mm}$ for kernel diameter, 73.09 and $66.29-78.74$ for kernel hardness index, and $79.35 \mathrm{~kg} / \mathrm{hl}$ and $78.84-80.18 \mathrm{~kg} / \mathrm{hl}$ for

Table 1

Physiochemical and pasting properties, fermentation efficiency, and bioethanol yield of grain sorghum samples.

\begin{tabular}{|c|c|c|c|c|c|c|c|c|c|c|c|c|}
\hline & \multicolumn{12}{|c|}{ Irrigation treatments ${ }^{\mathrm{a}}$} \\
\hline & \multicolumn{6}{|l|}{2015} & \multicolumn{6}{|l|}{2016} \\
\hline & 1 & 2 & 3 & 4 & 5 & 6 & 1 & 2 & 3 & 4 & 5 & 6 \\
\hline 1000 kernel weight $(\mathrm{g})$ & $29.61 a^{b}$ & $27.24 b$ & $26.04 c d$ & $25.52 \mathrm{cde}$ & 24.57ef & $23.47 \mathrm{~g}$ & $27.35 b$ & $26.46 b c$ & 25.49cde & 25.00de & $23.92 \mathrm{fg}$ & $22.10 \mathrm{~h}$ \\
\hline Kernel diameter (mm) & $2.60 a$ & $2.49 b$ & $2.45 b c$ & $2.36 \mathrm{~d}$ & 2.33de & $2.26 \mathrm{f}$ & $2.58 \mathrm{a}$ & $2.49 \mathrm{~b}$ & $2.44 c$ & $2.34 d$ & $2.29 \mathrm{ef}$ & $2.20 \mathrm{~g}$ \\
\hline Kernel hardness & $69.62 \mathrm{~g}$ & $70.91 \mathrm{fg}$ & 72.11ef & $73.46 \mathrm{~cd}$ & $74.73 \mathrm{bc}$ & $78.00 \mathrm{a}$ & $66.98 \mathrm{~h}$ & $70.56 \mathrm{~g}$ & 72.85de & $73.98 \mathrm{bcd}$ & $75.27 b$ & $78.60 \mathrm{a}$ \\
\hline Test weight $(\mathrm{kg} / \mathrm{hl})$ & $79.63 c$ & $79.54 c$ & 79.32de & $79.21 \mathrm{e}$ & $79.00 \mathrm{f}$ & $78.86 \mathrm{~g}$ & $80.18 a$ & $79.86 b$ & $79.41 d$ & $79.25 \mathrm{e}$ & $79.04 f$ & $78.87 \mathrm{~g}$ \\
\hline Starch (\%) & $72.81 \mathrm{a}$ & $72.78 \mathrm{a}$ & $72.74 a$ & $72.27 c$ & $71.63 d$ & $70.62 \mathrm{e}$ & $72.43 b$ & $72.29 c$ & $71.58 \mathrm{~d}$ & $70.33 \mathrm{f}$ & $69.51 \mathrm{~g}$ & $69.48 \mathrm{~g}$ \\
\hline Protein (\%) & $8.22 \mathrm{e}$ & $8.34 \mathrm{e}$ & $8.49 \mathrm{e}$ & 8.67e & $9.22 \mathrm{~d}$ & $10.27 b$ & $9.55 d$ & $9.80 \mathrm{~d}$ & $10.14 \mathrm{c}$ & $10.91 b$ & $11.42 \mathrm{a}$ & $12.46 a$ \\
\hline Fat $(\%)$ & 2.93abc & $2.92 \mathrm{abc}$ & $2.98 \mathrm{ab}$ & $2.94 \mathrm{ab}$ & $2.81 \mathrm{~cd}$ & $3.03 a$ & 2.72de & 2.71de & $2.63 e$ & 2.64de & 2.73 & $2.90 \mathrm{bc}$ \\
\hline Fiber (\%) & $1.42 \mathrm{~b}$ & $1.03 \mathrm{~d}$ & $1.19 \mathrm{c}$ & $1.06 \mathrm{~cd}$ & $1.05 \mathrm{~d}$ & 1.03 & 0.98de & $1.02 \mathrm{~d}$ & $1.02 \mathrm{~d}$ & $1.59 \mathrm{a}$ & $1.03 \mathrm{~d}$ & $0.87 e$ \\
\hline Pasting temperature $\left({ }^{\circ} \mathrm{C}\right)$ & $72.04 \mathrm{~g} 2$ & $73.18 f$ & 73.81e & $74.88 \mathrm{c}$ & $75.29 c$ & $76.22 \mathrm{a}$ & $72.66 \mathrm{~g}$ & $73.13 \mathrm{f}$ & $73.94 \mathrm{e}$ & $74.82 d$ & 75.71b & $76.83 a$ \\
\hline Peak time (min) & $5.13 \mathrm{e}$ & 5.17de & $5.24 \mathrm{~d}$ & $5.35 b c$ & $5.41 \mathrm{~b}$ & $5.56 a$ & 5.15de & $5.23 \mathrm{~d}$ & $5.26 \mathrm{~cd}$ & $5.37 \mathrm{~b}$ & $5.43 \mathrm{~b}$ & $5.60 a$ \\
\hline Peak viscosity (cP) & $3245 a$ & $3089 b$ & $3082 b$ & $2636 d$ & $2608 d$ & $2275 f$ & $3210 a$ & $3094 b$ & $2912 c$ & $2630 d$ & $2425 \mathrm{e}$ & $2171 \mathrm{~g}$ \\
\hline Holding strength (cP) & $1831 a$ & $1717 \mathrm{~cd}$ & $1718 \mathrm{~cd}$ & $1731 \mathrm{~cd}$ & $1765 b$ & $1618 f$ & $1755 b$ & 1689de & $1663 \mathrm{ef}$ & $1740 \mathrm{bc}$ & 1693de & 1645ef \\
\hline Breakdown (cP) & 1433a & $1415 a$ & 1359a & $963 c$ & $845 d$ & $653 e$ & $1419 a$ & $1404 a$ & $1189 b$ & $850 d$ & $718 \mathrm{e}$ & $531 \mathrm{f}$ \\
\hline Final viscosity $(\mathrm{cP})$ & $4603 c d$ & $4520 \mathrm{e}$ & $4566 \mathrm{~cd}$ & $4814 a$ & $4636 c$ & 4549d & 4528de & 4533de & $4720 b$ & $4568 \mathrm{~cd}$ & $4828 a$ & $4497 e$ \\
\hline Setback $(\mathrm{cP})$ & 2792de & 2816de & $2848 d$ & $3101 \mathrm{ab}$ & $2883 \mathrm{~cd}$ & $2946 c$ & $2753 e$ & $2853 d$ & $3028 b$ & 2800de & $3110 a$ & 2814de \\
\hline Fermentation efficiency (\%) & $89.79 b$ & $89.67 b$ & $89.07 b$ & 89.29 & $90.04 \mathrm{ab}$ & $91.88 \mathrm{a}$ & $89.79 b$ & $91.15 a$ & $90.55 a$ & $90.51 \mathrm{a}$ & $90.03 a$ & $91.47 a$ \\
\hline Bioethanol yield (ml/100g) & $47.96 a$ & $47.69 \mathrm{~b}$ & $47.02 \mathrm{c}$ & $46.30 \mathrm{bc}$ & $45.89 d$ & $45.06 \mathrm{~d}$ & $47.97 \mathrm{a}$ & $47.63 b$ & $46.85 b c$ & $46.14 \mathrm{c}$ & $45.61 d$ & $44.96 \mathrm{~d}$ \\
\hline
\end{tabular}

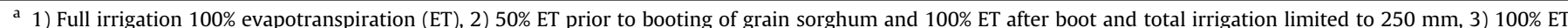

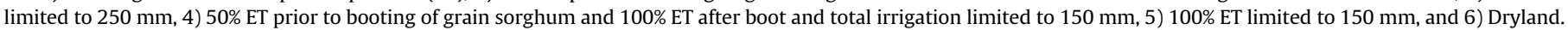

b Different letters indicate that the means in the same row are statistically significant at 5\% level. 
Table 2

Effects of deficit irrigation management, year and their interaction on physiochemical properties, pasting properties, fermentation efficiency, and bioethanol yield of sorghum samples.

\begin{tabular}{|c|c|c|c|}
\hline \multirow[t]{2}{*}{ Chemical composition/physical properties } & Irrigation treatment & Year & Irrigation $\times$ year \\
\hline & \multicolumn{3}{|l|}{$P>F$} \\
\hline 1000 kernel weight & $<0.05$ & $<0.05$ & 0.58 \\
\hline Kernel diameter & $<0.05$ & $<0.05$ & 0.15 \\
\hline Kernel hardness & $<0.05$ & 0.57 & 0.75 \\
\hline Test Weight & $<0.05$ & 0.66 & 0.77 \\
\hline Starch & $<0.05$ & $<0.05$ & $<0.05$ \\
\hline Protein & $<0.05$ & $<0.05$ & $<0.05$ \\
\hline Fat & $<0.05$ & 0.31 & 0.45 \\
\hline Fiber & $<0.05$ & 0.07 & 0.09 \\
\hline Pasting temperature & $<0.05$ & 0.49 & 0.89 \\
\hline Peak time & $<0.05$ & 0.70 & 0.62 \\
\hline Peak viscosity & $<0.05$ & 0.58 & 0.21 \\
\hline Holding strength & $<0.05$ & 0.11 & 0.56 \\
\hline Breakdown & $<0.05$ & 0.69 & 0.34 \\
\hline Final viscosity & $<0.05$ & 0.78 & 0.65 \\
\hline Setback & $<0.05$ & 0.65 & 0.51 \\
\hline Fermentation efficiency & $<0.05$ & 0.23 & 0.61 \\
\hline Ethanol yield & $<0.05$ & 0.12 & 0.51 \\
\hline
\end{tabular}

test weight. In Table 2, statistical analysis shows that not only deficit irrigation had a significant effect on 1000 kernel weight, kernel diameter, kernel hardness index, and test weight of sorghum, but also year showed a significant effect on 1000 kernel weight and kernel diameter, whereas the interaction between deficit irrigation and year was not a significant factor. As shown in Table 1, both 1000 kernel weight and kernel diameter of sorghum samples increased as the level of deficit irrigation decreased. These results were consistent with previous research on wheat where drought decreased both kernel weight and kernel diameter of winter wheat kernel (Weightman et al., 2008). Weightman et al. (2008) also reported that wheat grown under low irrigation capacity produced a higher kernel hardness index than wheat under high irrigation capacity, which was similar to the results in the current study. Sorghum grown under low levels of deficit irrigation produced higher test weight than sorghum grown under high levels of deficit irrigation. The highest test weight of $80.18 \mathrm{~kg} / \mathrm{hl}$ was achieved under full irrigation capacity or 100\% ET in 2016. Test weight of grain is an important indication of soundness and flour yield. Moreover, positive relationships were observed between 1000 kernel weight and kernel diameter $(\mathrm{R}=0.96$ and $P<0.01)$, 1000 kernel weight and test weight $(\mathrm{R}=0.78$ and $P<0.01)$, kernel diameter and test weight $(\mathrm{R}=0.89$ and $P<0.01)$ as shown in Table 3. However, kernel hardness negatively correlated with 1000 kernel weight, kernel diameter and test weight $(P<0.01)$.
Therefore, sorghum produced under full irrigation may be better feedstock for milling. All the sorghum test weight would fall in a "high test weight" category based on the criterion described by Paulsen and Hill (1985).

For all sorghum samples across the six irrigation treatments in 2015 and 2016, starch content of sorghum samples ranged from 69.45 to $72.81 \%$ with a mean value of $71.53 \%$; protein content ranged from $8.22 \%$ to $12.50 \%$ with a mean value of $9.78 \%$; fat content ranged from 2.61 to $3.06 \%$ with a mean value of $2.82 \%$; and fiber content ranged from 0.83 to $1.63 \%$ with a mean value of $1.11 \%$. Sorghum produced full irrigation produced $~ 3 \%$ more starch than sorghum produced under high deficit irrigation. The highest starch content was achieved in 2015 under 100\% ET irrigation treatment. An increasing trend of starch content was observed as level of irrigation capacity increased (Table 1). A significant effect of irrigation was observed for all the chemical components of sorghum. Nevertheless, year and interaction between deficit irrigation and year only had significant effects on starch and protein content, which was significantly higher in 2015 than 2016 (Table 2). The Pearson correlation shown in Table 3 revealed that starch content positively correlated to 1000 kernel weight, kernel diameter and test weight $(P<0.01)$, but negatively correlated to kernel hardness index $(\mathrm{R}=-0.79, P<0.01)$ and protein content $(\mathrm{R}=-0.94$, $P<0.01$ ). The highest protein content of $12.46 \%$ was found in 2016 for samples under the treatment that received least amount of

Table 3

Pearson correlation coefficient between Physiochemical properties, fermentation efficiency, and ethanol yield of sorghum samples.

\begin{tabular}{|c|c|c|c|c|c|c|c|c|c|c|}
\hline & 1000 kernel weight & Kernel diameter & Kernel hardness & Test weight & Starch & Protein & Fat & Fiber & $\begin{array}{l}\text { Fermentation } \\
\text { efficiency }\end{array}$ & $\begin{array}{l}\text { Bioethanol } \\
\text { yield }\end{array}$ \\
\hline 1000 kernel weight & 1 & $0.96^{* *}$ & $-0.89^{* *}$ & $0.78^{* *}$ & $0.83^{* *}$ & $-0.77^{* *}$ & -0.01 & 0.39 & $-0.56^{* *}$ & $0.93^{* *}$ \\
\hline Kernel diameter & $0.96^{* *}$ & 1 & $-0.96^{* *}$ & $0.89^{* *}$ & $0.84^{* *}$ & $-0.71^{* *}$ & -0.13 & 0.25 & $-0.50^{*}$ & $0.98^{* *}$ \\
\hline Kernel hardness & $-0.89^{* *}$ & $-0.96^{* *}$ & 1 & $-0.95^{* *}$ & $-0.79^{* *}$ & $0.64^{* *}$ & 0.25 & -0.20 & $0.55^{* *}$ & $-0.96^{* *}$ \\
\hline Test weight & $0.78^{* *}$ & $0.89^{* *}$ & $-0.95^{* *}$ & 1 & $0.67^{* *}$ & $-0.45^{*}$ & -0.33 & 0.08 & -0.31 & $0.92^{* *}$ \\
\hline Starch & $0.83^{* *}$ & $0.84^{* *}$ & $-0.79^{* *}$ & $0.67^{* *}$ & 1 & $-0.94^{* *}$ & 0.22 & 0.11 & $-0.59^{* *}$ & $0.85^{* *}$ \\
\hline Protein & $-0.77^{* *}$ & $-0.71^{* *}$ & $0.64^{* *}$ & $-0.45^{*}$ & $-0.94^{* *}$ & 1 & -0.36 & -0.22 & $0.66^{* *}$ & $-0.69^{* *}$ \\
\hline Fat & -0.01 & -0.13 & 0.25 & -0.33 & 0.22 & -0.36 & 1 & -0.14 & -0.08 & -0.16 \\
\hline Fiber & 0.39 & 0.25 & -0.20 & 0.08 & 0.11 & -0.22 & -0.14 & 1 & -0.24 & 0.21 \\
\hline $\begin{array}{l}\text { Fermentation } \\
\text { efficiency }\end{array}$ & $-0.56^{* *}$ & $-0.50^{*}$ & $0.55^{* *}$ & -0.31 & $-0.59^{* *}$ & $0.66^{* *}$ & -0.08 & -0.24 & 1 & $-0.51^{*}$ \\
\hline Bioethanol yield & $0.93^{* *}$ & $0.98^{* *}$ & $-0.96^{* *}$ & $0.92^{* *}$ & $0.85^{* *}$ & $-0.69^{* *}$ & -0.16 & 0.21 & $-0.51^{*}$ & 1 \\
\hline
\end{tabular}

${ }^{*}$ Correlation is significant at the 0.05 level (2-tailed).

${ }^{* *}$ Correlation is significant at the 0.01 level (2-tailed). 
irrigation. Low irrigation yielding high protein content of grain supports the observations of previous researchers (Daniel and Triboi, 2002; Weightman et al., 2008).

\subsection{Effect of deficit irrigation on pasting properties and thermal properties of grain sorghum}

The rheological characteristics of starch in sorghum samples were analyzed using RVA to evaluate the effect of deficit irrigation on pasting properties of sorghum. As shown in Table 1, for all of the sorghum samples, the mean and range across deficit irrigation levels and years were $74.37{ }^{\circ} \mathrm{C}$ and $71.95-76.89{ }^{\circ} \mathrm{C}$ for pasting temperature (the temperature starch granule start swelling and gelatinization), $5.32 \mathrm{~min}$ and 5.12-5.61 min for peak time, $2781 \mathrm{cP}$ and 2157-3249 cP for peak viscosity (the maximum viscosity during heating and starch gelatinization), $1713 \mathrm{cP}$ and $1612-1836 \mathrm{cP}$ for holding strength (an indicator of the water holding capacity of starch), $1064 \mathrm{cP}$ and 501-1442 cP for breakdown (the starch granule rupturing and releasing amylose), $4613 \mathrm{cP}$ and $4461-4834 \mathrm{cP}$ for final viscosity, $2895 \mathrm{cP}$ and $2745-3146 \mathrm{cP}$ for setback. In Table 4, a Pearson correlation shows that pasting temperature positively correlated to peak time and setback but negatively correlated to peak viscosity, holding strength, and breakdown $(P<0.05)$. These results are in good agreement with previous studies (Liu et al., 2013; Wu et al., 2008). A significant effect of deficit irrigation was observed for all RVA parameters, whereas either year or interaction between deficit irrigation and year did not show significant influence (Table 2). For this reason, RVA curves of sorghum samples with different deficit irrigation in 2015 was selected and demonstrated in Fig. 1a. Sorghum under high irrigation had lower pasting temperature and peak time, higher peak viscosity, holding strength, and breakdown than that under low irrigation sorghum. The lower pasting temperature and peak time was related to the fact that the starch granules were more susceptible to swelling and gelatinizing (Saunders et al., 2011). Higher peak viscosity, holding strength, and breakdown associated with the increased accessibility of starch to enzymes, thereby enhancing the liquefaction process during bioethanol production (Wu et al., 2007). The low level of deficit irrigation being favorable for sorghum targeted to bioethanol production was confirmed by the Pearson correlation coefficient between pasting properties and bioethanol yield (Table 4). Bioethanol yield significantly correlated to pasting temperature $(\mathrm{R}=-0.98 P<0.01)$, peak time $(R=-0.97 P<0.01)$, peak viscosity $(R=0.98 P<0.01)$, and breakdown $(R=0.97 P<0.01)$, respectively.

The DSC curves of sorghum under different deficit irrigation levels planted in 2015 are shown in Fig. 1b. Despite that no clear trend was observed between years, deficit irrigation showed a significant influence on onset temperature (the temperature starch start gelatinization) and peak temperature (the temperature starch completely gelatinization). Sorghum grown under full irrigation had lower onset and peak temperature than sorghum grown under high levels of deficit irrigation. Low onset and peak temperature had a positive impact on bioethanol production because as less energy is needed to initiate the starch gelatinization (Barichello et al., 1990). In addition to the main starch gelatinization peak located at $75-78{ }^{\circ} \mathrm{C}$, there was a second peak around $102-104{ }^{\circ} \mathrm{C}$ except under full irrigation capacity. Amylose-lipid complexes were likely responsible for this peak, which are an unfavorable factor during bioethanol production as these complexes reduced the access of enzymes to starch. Similar conclusions were drawn for sorghum. Similar conclusions were drawn from previous studies where sorghum grain produced under high irrigation produced high bioethanol yield (Liu et al., 2013; Wu et al., 2008).

\subsection{Effect of deficit irrigation on fermentation efficiency and bioethanol yield of grain sorghum}

The fermentation efficiency and bioethanol yield of all sorghum samples across different deficit irrigation levels and year ranged from 88.98 to $91.91 \%$ and $44.94-47.99 \mathrm{~mL} / 100 \mathrm{~g}$ (Table 1 ). A significant effect of irrigation capacity was observed for bioethanol yield of sorghum (Table 2). Bioethanol yield of sorghum increased as deficit irrigation level with the highest bioethanol yield achieved in 2015 under full irrigation. Bioethanol yield of sorghum increased as irrigation level increased. Sorghum grown under full irrigation yielded $3 \mathrm{~mL}$ bioethanol per $100 \mathrm{~g}$ feedstock than sorghum grown under deficit irrigation using current approaches. While there was no significant correlation between final fermentation efficiency and deficit irrigation level, Fig. 1c demonstrates a clear trend that sorghum grown under low irrigation higher fermentation efficiency in the first $48 \mathrm{~h}$ of fermentation than sorghum grow under full irrigation sorghum. This was kindly due to sorghum grown under deficit irrigation having lower starch content and higher protein content, which would produce higher fermentation efficiency in the early stage of when inoculating the same amount of yeast per sample (i.e. a higher yeast to starch ratio), and high protein samples may have higher freer amino acid content as nutrient for yeast. This result was confirmed by Person correlation analysis between grain physiochemical traits/pasting properties and fermentation efficiency. Starch and protein content of sorghum and peak time and final viscosity of starch pasting did not have a significant relationship $(P>0.05)$ to fermentation efficiency (Tables 3 and 4). However, the Person correlation analysis showed that bioethanol yield had significant correlation with all physiochemical and pasting properties. Supplement 1 shows the relationship between starch content of sorghum and bioethanol yield and fermentation efficiency. Although starch content is the most import predictor in bioethanol

Table 4

Pearson correlation coefficient between pasting properties, fermentation efficiency, and bioethanol yield of sorghum samples.

Pasting temperature Peak time Peak viscosity Holding strength Breakdown Final viscosity Setback Fermentation efficiency Bioethanol yield

\begin{tabular}{|c|c|c|c|c|c|c|c|c|c|}
\hline Pasting temperature & 1 & $0.97^{* *}$ & $-0.98^{* *}$ & $-0.62^{* *}$ & $-0.96^{* *}$ & 0.18 & $0.41^{*}$ & $0.49^{*}$ & $-0.98^{* *}$ \\
\hline Peak time & $0.97^{* *}$ & 1 & $-0.97^{* *}$ & $-0.63^{* *}$ & $-0.95^{* *}$ & 0.08 & 0.32 & $0.61^{* *}$ & $-0.97^{* *}$ \\
\hline Peak viscosity & $-0.98^{* *}$ & $-0.97^{* *}$ & 1 & $0.58^{* *}$ & $0.98^{* *}$ & -0.19 & $-0.41^{*}$ & $-0.55^{* *}$ & $0.98^{* *}$ \\
\hline Holding strength & $-0.62^{* *}$ & $-0.63^{* *}$ & $0.58^{* *}$ & 1 & $0.50^{*}$ & 0.05 & -0.34 & $-0.66^{* *}$ & $0.58^{* *}$ \\
\hline Breakdown & $-0.96^{* *}$ & $-0.95^{* *}$ & $0.98^{* *}$ & $0.50^{*}$ & 1 & -0.21 & -0.37 & $-0.51^{* *}$ & $0.97^{* *}$ \\
\hline Final viscosity & 0.18 & 0.08 & -0.19 & 0.05 & -0.21 & 1 & $0.88^{* *}$ & -0.35 & -0.20 \\
\hline Setback & $0.41^{*}$ & 0.32 & $-0.41^{*}$ & -0.34 & -0.37 & $0.88^{* *}$ & 1 & -0.05 & $-0.42^{*}$ \\
\hline Fermentation efficiency & $0.49^{*}$ & $0.61^{* *}$ & $-0.55^{* *}$ & $-0.66^{* *}$ & $-0.51^{* *}$ & -0.35 & -0.05 & 1 & $-0.50^{*}$ \\
\hline Bioethanol yield & $-0.98^{* *}$ & $-0.97^{* *}$ & $0.98^{* *}$ & $0.58^{* *}$ & $0.97^{* *}$ & -0.20 & $-0.42^{*}$ & $-0.50^{*}$ & 1 \\
\hline
\end{tabular}

*Correlation is significant at the 0.05 level (2-tailed).

** Correlation is significant at the 0.01 level (2-tailed). 

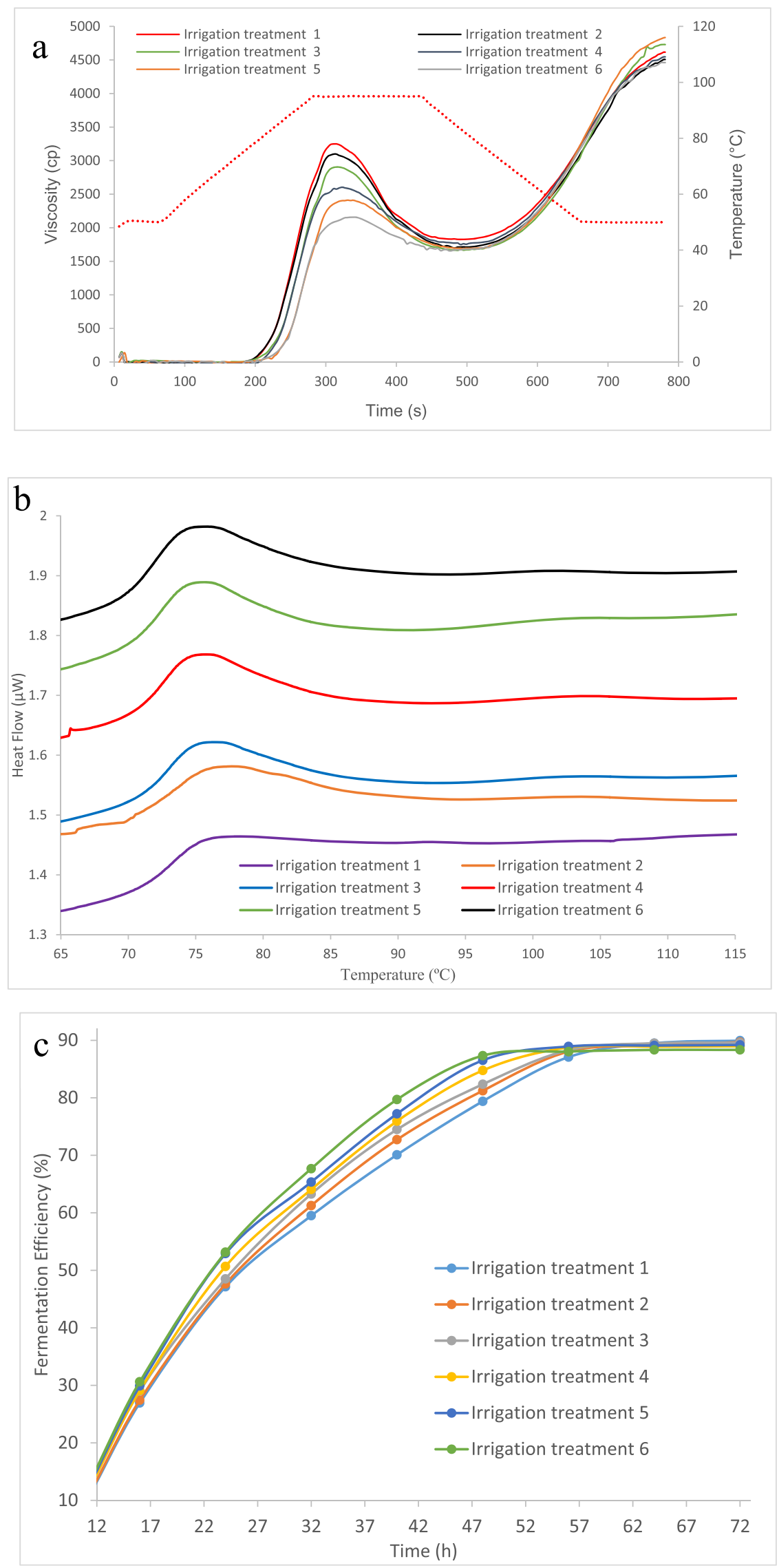

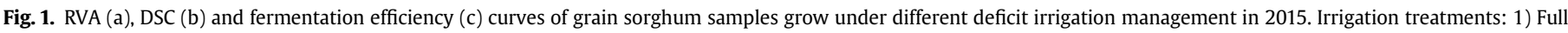

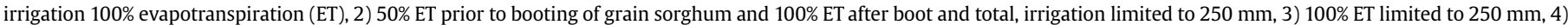
$50 \%$ ET prior to booting of grain sorghum and 100\% ET after boot and total irrigation limited to $150 \mathrm{~mm}, 5$ ) $100 \%$ ET limited to $150 \mathrm{~mm}$, and 6 ) dryland. 

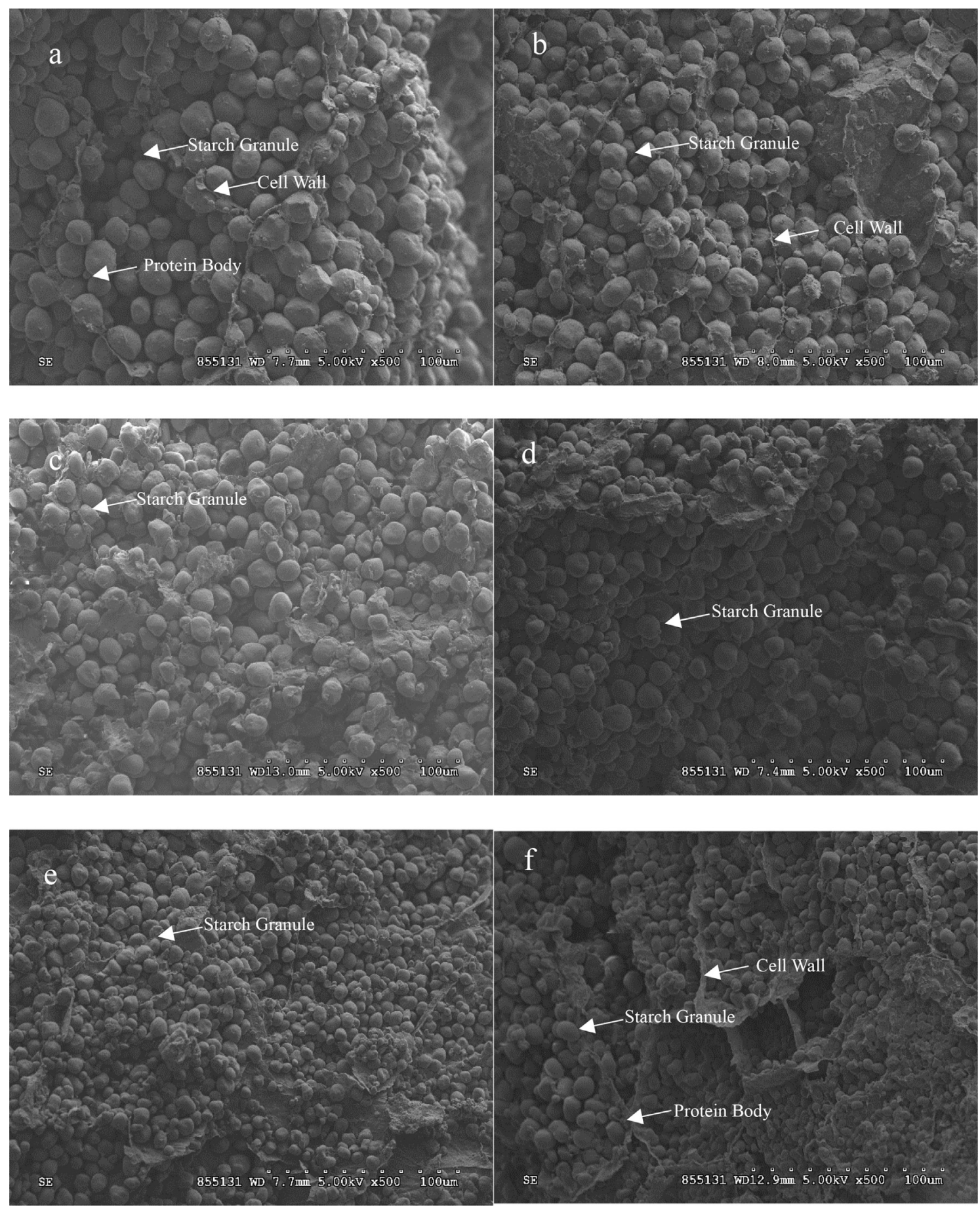

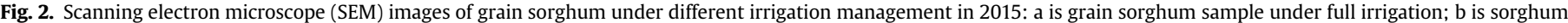

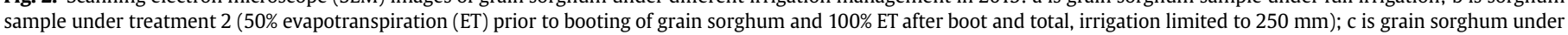

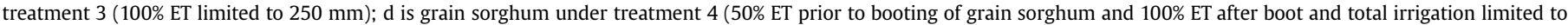
$150 \mathrm{~mm}$ ); e is grain sorghum sample under treatment 5 (100\% ET limited to $150 \mathrm{~mm}$ ); and f is grain sorghum under treatment 6 (dryland).

yield $\left(R^{2}=0.71\right)$, it did not correlate to fermentation efficiency. Of irrigation capacity, sorghum grown under high full irrigation produced greater starch and bioethanol than sorghum grown under deficit irrigation. Table 2 shows that both year and interaction between deficit irrigation level and year did not have significant effects on fermentation efficiency and bioethanol yield of sorghum. This is probably due to above normal rainfall received during the growing seasons.

\subsection{Effect deficit irrigation on morphological properties of grain sorghum}

Scanning electron microscope images of sorghum samples under different deficit irrigation levels is shown in Fig. 2. Sorghum produced under full irrigation (Fig. 2 a) had larger starch granule size than the sorghum produced under moderate (Fig. 2 b-e) and high deficit irrigation levels (Fig. $2 \mathrm{f}$ ). These results fit the fact that 
sorghum under full irrigation had higher starch content and bioethanol yield than sorghum under high level of deficit irrigation. In addition, the sorghum grown under full irrigation capacity had more protein bodies surrounding the starch granule than those grown under deficit irrigation. Wu et al. (2008) reported the similar findings in that sorghum from irrigated land had various degrees of association with protein bodies compared with sorghum from dry land. A greater number of protein bodies surrounding starch granules may result in a stronger protein matrix, or at least reduced access of enzymes to starch, which has negative effect on fermentation efficiency. This may be another reason why the sorghum grown under full irrigation has a lower fermentation efficiency than that those grown under deficit irrigation in the first $48 \mathrm{~h}$ of fermentation.

Another factor affecting fermentation efficacy is field-sprouted grain. Yan et al. (2010) reported that more holes were found on the surface of starch granules from field-sprouted grain, which also had higher fermentation efficacy than non-sprouted samples. There were some pinholes seen on the surface of starch granules from sorghum grown under full irrigation (Fig. 2 a). Sorghum grown under full irrigation showed weaker cell wall than that these grown under deficit irrigation, indicating that grain sorghum under full irrigation may be a better feedstock for starch yield during wet milling (Perez-Carrillo and Serna-Saldivar, 2006).

\section{Conclusions}

Grain sorghum with good adaption for production under both irrigated and dryland environments was planted under six different deficit irrigation management in 2015 and 2016. The starch content of all sorghum samples ranged from 69.45 to $72.82 \%$, protein content ranged from 8.22 to $12.50 \%$, bioethanol yield ranged from 44.94 to $47.99 \mathrm{~mL} / 100 \mathrm{~g}$. The level of deficit irrigation had a significant effect on all physiochemical properties, pasting properties, and bioethanol yield. Starch content and bioethanol yield increased as irrigation level increased across two growing seasons. However, no significant effect of year and interaction between deficit irrigation and year on various properties and bioethanol yield was overserved except starch and protein contents, which was significantly higher in 2015 than that in 2016.

\section{Acknowledgements}

The authors would like to thank the following for organizations for partially funding this research: U.S. Department of Agriculture Ogallala Aquifer Project, Kansas Grain Sorghum Commission, Kansas Water Resources Institute and The Foundation for Food and Agricultural Research (Award \# 430871), as well as the Kansas Center for Agricultural Resources and the Environment and Kansas Water Resources Institute. This is contribution no. 17-351-J of the Kansas Agricultural Experiment Station.

\section{Appendix A. Supplementary data}

Supplementary data related to this article can be found at https://doi.org/10.1016/j.jcs.2017.09.002

\section{References}

Araya, A., Kisekka, I., Holman, J., 2016. Evaluating deficit irrigation management strategies for grain sorghum using AquaCrop. Irrigation Sci. 34, 465-481.

Barichello, V., Yada, R., Coffin, R., Stanley, D., 1990. Low temperature sweetening in susceptible and resistant potatoes: starch structure and composition. J. Food Sci. 55, 1054-1059.

Bean, S., Chung, O., Tuinstra, M., Pedersen, J.F., Erpelding, J., 2006. Evaluation of the Single Kernel Characterization System (SKCS) for Measurement of Sorghum Grain Attributes.

Berhe, A.A., Kisekka, I., Prasad, P.V., Holman, J., Foster, A.J., Lollato, R., 2017. Assessing Wheat Yield, Biomass, and Water Productivity Responses to Growth Stage Based Irrigation Water Allocation.

Chai, Q., Gan, Y., Zhao, C., Xu, H.-L., Waskom, R.M., Niu, Y., Siddique, K.H., 2016. Regulated deficit irrigation for crop production under drought stress. A review. Agron. Sustain. Dev. 36, 3.

Conca, J., 2014. It's Final - Corn Ethanol Is of No Use.

Daniel, C., Triboi, E., 2002. Changes in wheat protein aggregation during grain development: effects of temperatures and water stress. Eur. J. Agron. 16, 1-12.

El-Hendawy, S.E., Hassan, W.M., Al-Suhaibani, N.A., Schmidhalter, U., 2017. Spectra assessment of drought tolerance indices and grain yield in advanced spring wheat lines grown under full and limited water irrigation. Agric. Water Manag. $182,1-12$.

Irmak, S., Djaman, K., Rudnick, D.R., 2016. Effect of full and limited irrigation amount and frequency on subsurface drip-irrigated maize evapotranspiration, yield, water use efficiency and yield response factors. Irrigation Sci. 34, 271-286.

Kisekka, I., Lamm, F., Schlegel, A., 2016. Sorghum yield response to water supply and irrigation management. Kans. Agric. Exp. Stn. Res. Rep. 2, 7.

Klocke, N., Currie, R., Tomsicek, D., Koehn, J., 2012. Sorghum yield response to deficit irrigation. Trans. ASABE 55, 947-955.

Liu, L., Maier, A., Klocke, N.L., Yan, S., Rogers, D.H., Tesso, T., Wang, D., 2013. Impact of deficit irrigation on sorghum physical and chemical properties and ethanol yield. Trans. ASABE 56, 1541-1549.

McGuire, V.L., 2012. Water-level and storage changes in the High Plains aquifer, predevelopment to 2011 and 2009-11.

Paulsen, M., Hill, L., 1985. Corn quality factors affecting dry milling performance. J. Agric. Eng. Res. 31, 255-263.

Perez-Carrillo, E., Serna-Saldivar, S.O., 2006. Cell wall degrading enzymes and proteases improve starch yields of sorghum and maize. Starch-Stärke 58, 338-344.

RFA, 2016. The 2016 Ethanol Industry Outlook.

Saunders, J., Levin, D.B., Izydorczyk, M., 2011. Limitations and Challenges for Wheatbased Bioethanol Production. INTECH Open Access Publisher.

Stone, L.R., Schlegel, A.J., 2006. Yield-water supply relationships of grain sorghum and winter wheat. Agron. J. 98, 1359-1366.

USDA-ERS, 2016. Irrigation \& Water Use.

Van Donk, S., Martin, D.L., Irmak, S., Melvin, S.R., Petersen, J., Davison, D., 2010. Crop residue cover effects on evaporation, soil water content, and yield of deficitirrigated corn in west-central Nebraska. Trans. ASABE 53, 1787-1797.

Weightman, R.M., Millar, S., Alava, J., Foulkes, M.J., Fish, L., Snape, J.W., 2008. Effects of drought and the presence of the $1 \mathrm{BL} / 1 \mathrm{RS}$ translocation on grain vitreosity, hardness and protein content in winter wheat. J. Cereal Sci. 47, 457-468.

Wu, X., Zhao, R., Bean, S., Seib, P., McLaren, J., Madl, R., Tuinstra, M., Lenz, M., Wang, D., 2007. Factors impacting ethanol production from grain sorghum in the dry-grind process. Cereal Chem. 84, 130-136.

Wu, X., Zhao, R., Liu, L., Bean, S., Seib, P., McLaren, J., Madl, R., Tuinstra, M., Lenz, M., Wang, D., 2008. Effects of growing location and irrigation on attributes and ethanol yields of selected grain sorghums. Cereal Chem. 85, 495-501.

Yan, S., Wu, X., Bean, S.R., Pedersen, J.F., Tesso, T., Chen, Y., Wang, D., 2011. Evaluation of waxy grain sorghum for ethanol production. Cereal Chem. 88, 589-596.

Yan, S., Wu, X., Dahlberg, J., Bean, S.R., MacRitchie, F., Wilson, J.D., Wang, D., 2010. Properties of field-sprouted sorghum and its performance in ethanol production. J. Cereal Sci. 51, 374-380.

Zhang, K., Zheng, G., Saul, K., Jiao, Y., Xin, Z., Wang, D., 2017. Evaluation of the multiseeded (msd) mutant of sorghum for ethanol production. Industrial Crops Prod. 97, 345-353.

Zhang, L., Wang, R., Zhang, C., Wang, S., Xu, T., 2016. Intelligent irrigation strategy based on regulated deficit theory and fuzzy control for rice in cold region. Trans. Chin. Soc. Agric. Eng. 32, 52-58. 


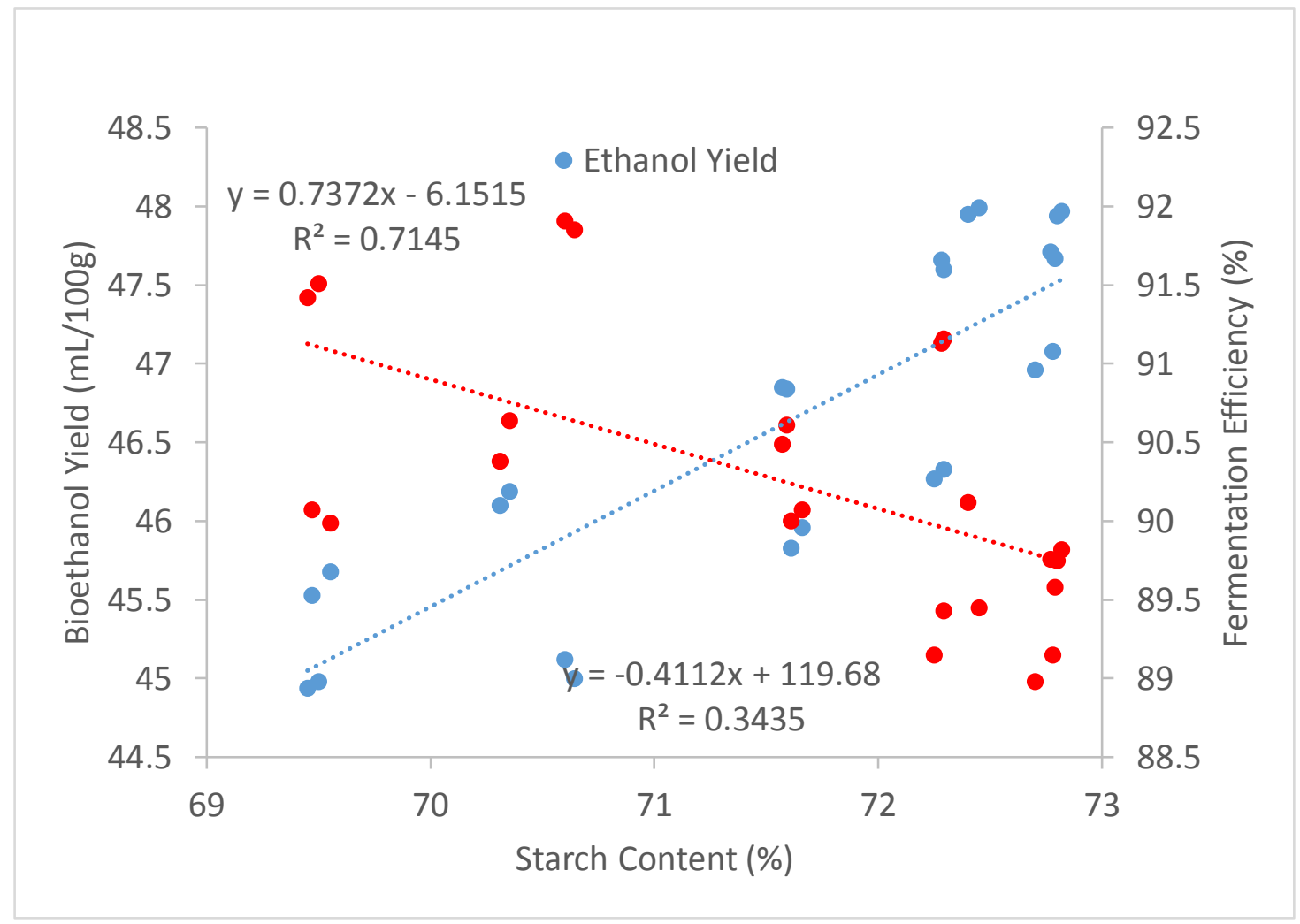

Supplement 1. Starch content of sorghum versus bioethanol yield and fermentation efficiency. 